\title{
Parents' Perception of Online Learning During the Covid-19 Pandemic: A Literature Review Study
}

\author{
Sonia Johanisa ${ }^{1 *}$, Nurul Fadila², Yucke Kartika Desma ${ }^{3}$, Nurul Afnita ${ }^{4}$, Hadi \\ Husnaini $^{5}$ \\ ${ }^{12345}$ Students of Univesitas Jambi \\ *Corresponding authors. Email: Soniajohanisa96@gmail.com
}

\begin{abstract}
In response to the Covid-19 outbreak, schools have been closed nationwide by the Indonesian government, due to the prevention of the spread of infection. this is done as an emergency measure. besides that, public activities are also limited. This situation challenges education in the world, especially in Indonesia and forces learning to shift to online learning. online learning diversion is a part of many educational institutions in the world. several factors related to the quality of educational institutions, teachers, parents, students and added to the levies on the condition of the students conditions are a big influence on the quality of online learning. this situation places parents and guardians in the responsibility of learning. The articles reviewed on this topic come from Indonesia and internationally.
\end{abstract}

Keywords: Parents' Perception, Online Learning, Covid-19 Pandemic.

\section{INTRODUCTION}

In early 2020, the global COVID-19 outbreak will change many aspects of life, including education. Indonesia is no exception. The challenges of dealing with the epidemic have led world leaders to enforce strict rules to limit the spread of COVID-19. In Indonesia, the number of infected with COVID-19 is increasing every day, hence a "massive social ban" "Enacted" in March 2020. [1].

Social distancing has been implemented by the Indonesian government which has an impact on community and student activities in the learning system. One alternative solution in the world of education is to create distance learning or what can be called the Work From Home (WFH) system. The program aims to transfer activities and teaching processes that were initially carried out in schools and now transferred at home. Based on a circular from the Ministry of Education and Culture that schools must manage online learning to meet all curriculum requirements. In addition, WFH is held considering the health and safety of scholars, educators, education personnel, and the community. These changes forced schools to implement distance education or better known as online learning (E-Learning). This is applied considering that learning must continue and for the continuity of education during a pandemic.

Learning activities from home are carried out by assignments. Coordination related to assignments is carried out using the WhatsApp application between the teacher and parents of students. Therefore, online learning requires parents to be able to accompany their children while studying from home. Based on the problems, researcher interested to knowing the concept of perception related to online learning and the perception of parents towards online learning faced by parents through a literature review.

\section{THE CONCEPT OF PERCEPTION RELATED TO ONLINE LEARNING}

Changes in the learning process will require schools to provide online-based education. the same is true in the United States. According to the Centers for Disease Control [2], electronic learning programs that include digital and distance learning methods are effective and widely implemented to ensure student academic progress during the COVID-19 epidemic. For example, in February 2020, China has implemented online learning or so-called e-learning, this is done so that student education continues, In 
April 2020, in Bulgaria, the Ministry of Education and Science has launched a system for e-learning. not only that, in Finland, all educational activities are carried out digitally and if necessary they apply independent learning to students.

Indonesia itself has many solutions to support online learning, including online learning that emphasizes online-based courses, providing learning through direct interaction between students and teachers, and the use of online forms such as meetings and discussions. online. Then learn directly (not simultaneously) using an independent learning process. Some topics are designed and displayed on Google Scholar, Moodle or email systems, blogs, online discussions, Wikipedia, video, news, Kahoot application, Duolingo application in mobile phone or computer and other platforms.

The epidemiology of Covid-19 changes the learning process from face-to-face learning to distance learning. According to Michotte [3], we broaden our understanding as a time frame of all naturals process that can adapt our actions to the world in which we live. Here, parental understanding requires flexibility, which can be described as a concept developed after acquiring certain skills. Limited technological knowledge is one of the problems in this learning process. In this case, parents need to educate their children online based on learning. This is not a problem for parents of students who are accustomed to using technology, but for parents of students who have not used technology, teaching children in situations like this can be a challenge. Of course this is not easy for all educators, especially parents, to face this curriculum transition. Previously, even materialistic parents did not have much time to mentor their children. The situation changed today. Parents need to support and create an effective environment for online learning activities. On the other hand, parents need to partner with teachers to create an environment that supports children's activities in school [4]. Parents spend more time developing their children and developing emotional bonds than ever before. The role of parents in this curriculum cannot be denied. While doctors are at the forefront of hiding Covid-19, mothers and fathers are leading the protection of children's theory so that they do not continue to study at home.

\section{THE ROLE OF PARENTS TO EDUCATION}

Parents are the first and most educators of their children. In the case of higher education, parents must ensure that their children receive the appropriate support and education for their education and learning. Therefore, parental involvement and supervision can have a positive impact on the development of motivational development and the formation of positive behavior in children. Unlike traditional learning environments, the role of parents and their impact on student success is important and clear. Parents always educate and support students through the curriculum. Parents also play an important role in student learning online so that they can guide and encourage students to roam the school. Since the onset of the disease, parents have faced new challenges as parents and educators. Parents play an important role in supporting by supporting their child in their homework and activities. Encouraging and supporting parents for home learning activities, including parent involvement in school education, is essential to a child's education. Research studies show the building of effective partnerships between parents, families and schools to support children's learning in improving learning outcomes. Teachers, parents, and schools need to strengthen collaboration to improve performance and behavior.

Therefore, the role of parents is needed as a substitute for teachers at home in guiding their children during the online learning process. According to Winingsih [5] there are four roles of parents during School from Home (SFH):

1. Parents have a role as teachers at home, where parents can guide their children in online learning.

2. Parents as facilitators, parents as means and prefacilities for their children to carry out online learning.

3. Parents as motivators, namely parents can provide encouragement and support to their children in implementing online learning, so that children have the enthusiasm to learn and get good achievements.

\section{Parents as influencers or leaders.}

Involvement in parenting is an important factor in student success in a traditional school environment. Parental support has shown a significant contribution to student success in the learning environment of perfection. The best vision for student success is the level at which family encourages learning at home and is part of a child's education. When parents get involved in their child's school life, students not only get the support and education they need to complete homework, but also to enhance the learning life cycle. Studies have shown that parental involvement affects not only learning outcomes, but also students' social, emotional, behavioral, and social development. Highly valued parental involvement includes partnerships between families, schools and communities, raising parental awareness of the benefits of children's education, experimenting and providing skills for it. Due to the many positions and influences of parents in their children's education, learning is very important to knowing their wealth and understanding of reading online. Because of many 
roles and influences of parents on children's education, it is very important to know the availability and perceptions of parents towards online learning.

\section{PERCEPTIONS OF PARENTS RELATED TO ONLINE LEARNING}

Online learning during the Covid-19 pandemic make parents have a lot of time with their children, they could accompany and guide children when learning. Therefore, parents must be able to guide children in a continuing, especially during the Covid19 pandemic where children are required to learn from home. When at school, children receive guidance from their teacher. So when at home, children should get guidance and involvement from their parents. There are many literatures that recognizes parental involvement's critical role in students' educational development [6]. Parents must realize that the importance of providing support for children's education, and not only parents who have an important role but teachers and the government also take part in supporting children's education. Support from parents, teachers, and the government (central and local) is needed in the SFH process. Involvement of parents, teachers, and the goverment is a collaborative effort in essential to successful online learning.

Based on previous research, parents argue that the involvement of parents in online learning is very important in the success of children's education. Then they agree that online learning during the Covid-19 pandemic can make them more compact with children. Togetherness can be realized through learning activities while playing with children. Resemblance, the research conducted by Erdener and Knoeppel [7] suggests that the parents accept that parental involvement is an important factor influencing children's educational success without giving up the idea education is school's responsibility.

In the assignments given by the teacher, one of them asks for cooperation between parents and children to complete the task. Cohesiveness makes children feel closer to their parents. Maintaining cohesiveness with children can have an effect on children's growth and development, children grow into better personalities and they will not be affected by negative things. With online learning, parents can get to know the child's attitude and character. Parents need to know the child's attitude and character, because of parents have to direct the child and guide the child to positive things. Parents have an important role in character education for children, because parents are the closest to children. Parents are the smallest miniature of society which is obliged to educate their children become moral and ethical societies.
In addition, under the guidance of the teacher, we do it with the cooperation of parents. The leadership system presents many challenges that face parents. Studying at home is an additional task for parents. Parents need to make sure their children are well educated. Parents should be temporary teachers and teach their children if they do not understand the problem at hand. Highly active parents should devote time to their child during their online studies. Parents need to encourage their children to study from home and not get tired too quickly. Parents argue that studying online at home has given birth to children. Online education can lead to children becoming overwhelmed because they cannot read with friends or meet teachers on their own. According to Aulia Luqman Aziz [8], an education expert at the University of Brawijaya, good learning is face-to-face learning between teachers and students. This interaction allows students to add social, cultural, ethical and moral value.

the role of parents is very important in learning and even the role of parents has been involved since early childhood. At high school, the role of parents is one of the important times in which parents can connect with their children's education and can regulate children's social welfare and children's emotions. however, parents usually spend their teenage years just balancing the need for independence and the need for family support. According to Goodall [9], parental involvement starts from the little children and will continue to be involved until the child reaches middle school. once again, parents play a very important role in the online learning process, because during $\mathrm{SFH}$ children can discuss with their parents about the tasks that the school is asked to do. Besides that, parents can also arrange children's tasks to make it easier to understand and also parents can find out the strength and comfort of the child.

\section{CONCLUSION}

The COVID-19 pandemic has brought major changes in the Indonesian education system, starting from classes that are physically changed to classes based on online. online learning or e-learning is a solution for public safety and health as well as academic activities. it requires teachers and students to carry out learning activities from home. In fact, things like that present a new polemic in the world of education in Indonesia, where obstacles or problems are found in disadvantaged areas. parents also change the role of being a teacher, even though their efforts are often unable to cope with tasks beyond their competence. this study concluded that parents are still not ready for rapid learning changes. One of the basic reasons is that parents have problems accompanying their children to study. Besides that, the biggest 
obstacle for parents is the difficulty in directing children to learn and the limited time.

The good news is that parents report that online learning can improve students 'reading quality by providing access to a variety of reading materials. And many parents believe that studying at home can strengthen their relationships with their children, allowing them to learn better online. Parents also feel that by reading online parents can see their children's learning progress. Most parents enjoy this school from home (SFH). The lesson from now on is that parents can get closer to their relatives because they have more time at home. Another lesson is to have patience in the learning and understanding that accompanies the activities of teachers in school. Finally, education should be seen as a community partnership between governments, teachers, parents and schools, promoting effective teaching and learning methods that have a negative impact and keeping students on track

\section{SUGGESTION}

The coronavirus pandemic (COVID-19) has brought new challenges to all social groups around the world, including families in Indonesia. Nowadays technology is the most important part in carrying out the online learning process during covid-19. Based on this report, there are some provides suggestions to the following parties: Teachers are expected to provide learning innovations so that learning is not monotonous while studying at home, Parents are expected to be more have time for student when studying at home.

\section{AUTHOR CONTRIBUTIONS}

This paper is single author research, where S.J is conceiving and design the paper, collecting the data, performed the analysis, writing and editing the paper.

\section{ACKNOWLEDGMENT}

This paper supported by Master of English Education of Jambi University.

\section{REFERENCES}

[1] Regulation of Indonesian Goverment No.21, 2020. (2020). Large-scale social restrictions in order to accelerate the handling of Corona Virus Disease 2019 (Covid-19). https://setkab.go.id/inilah-pp-pembatasan-sosialberskala-besar-untuk-percepatanpenanganancovid-19/

[2] Center for Disease Control and Prevention. (2020). Coronavirus Disease 2019 (COVID-19): Cases in the U.S. Retrieved from https://www. cdc.gov/coronavirus/2019-ncov/casesupdates/cases-in-us.html

[3] A. Michotte, (2019). The Perception of Causality (1st ed). London: Routledge.

[4] M. LaRocque, I. Kleiman, \& S. M. Darling, (2011). Parental involvement: The missing link in school achievement. Preventing School Failure, 55(3), 115-122.

[5] E. Winingsih. (2020). The Role of Parents in Distance Learning. April 2nd, 2020. Poskita.co: https://poskita.co/2020/04/02/peran-orang Tuadalampembelajaran-jarak-jauh/

[6] R. Al-Mahrooqi, C. Denman, \& F. Al-Maamari. (2016). Omani parents' involvement in their children's English education. SAGE Open, 6(1), $1-12$

[7] M. A. Erdener, \& R. C. Knoeppel, (2018). Parents' perceptions of their involvement in schooling. International Journal of Research in Education and Science, 4(1), 1-13.

[8] A.P. Kasih, (2020). Learning from Covid-19, UB Experts: The Role of Teachers is Not Changed by Technology.https://edukasi.kompas.com/read/20 20/05/04/140605771/belajar-dari-covid-19pakar-ub-peran-guru-no-changeable technology? page $=$ all

[9] J. Goodall, (2013). Parental engagement to support children's learning: a six-pointmodel. School Leadership \& Management, 33(2), 133150. doi:10.1080/13632434.2012.724668. 